\title{
Living with Volcanic Risk in the Cascades
}

he Cascade Range of the Pacific
Northwest has more than a dozen
potentially active volcanoes. Cascade
volcanoes tend to erupt explosively,
and on average two eruptions occur
per century-the most recent were at
Mount St. Helens, Washington (1980-86
and 2004-8), and Lassen Peak, Cali-
fornia (1914-17). To help protect the
Pacific Northwest's rapidly expand-
ing population, USGS scientists at
the Cascades Volcano Observatory
in Vancouver, Washington, monitor
and assess the hazards posed by the
region's volcanoes.

On May 18, 1980, after 2 months of earthquakes and minor eruptions, Mount St. Helens, Washington, exploded in one of the most devastating volcanic eruptions of the 20th century. Although less than 0.1 cubic mile of molten rock (magma) was erupted, 57 people died, and damage exceeded $\$ 1$ billion. Fortunately, most people in the area were able to evacuate safely before the eruption because public officials had been alerted to the danger by U.S. Geological Survey (USGS) and other scientists. As early as 1975, USGS researchers had warned that Mount St. Helens might soon erupt. Coming more than 60 years after the last eruption in the Cascades (Lassen Peak), the explosion of St. Helens was a spectacular reminder that the millions of residents of the Pacific Northwest share the region with live volcanoes.

\section{Volcanoes of the Cascades}

The volcanoes of the Cascade Range, which stretches from northern California into British Columbia, have produced more than 100 eruptions, most of them explosive, in just the past few thousand years. However, individual Cascade volcanoes can lie dormant for many centuries between eruptions, and the great risk posed by volcanic activity in the region is therefore not always apparent.

When Cascade volcanoes do erupt, high-speed avalanches of hot ash and rock

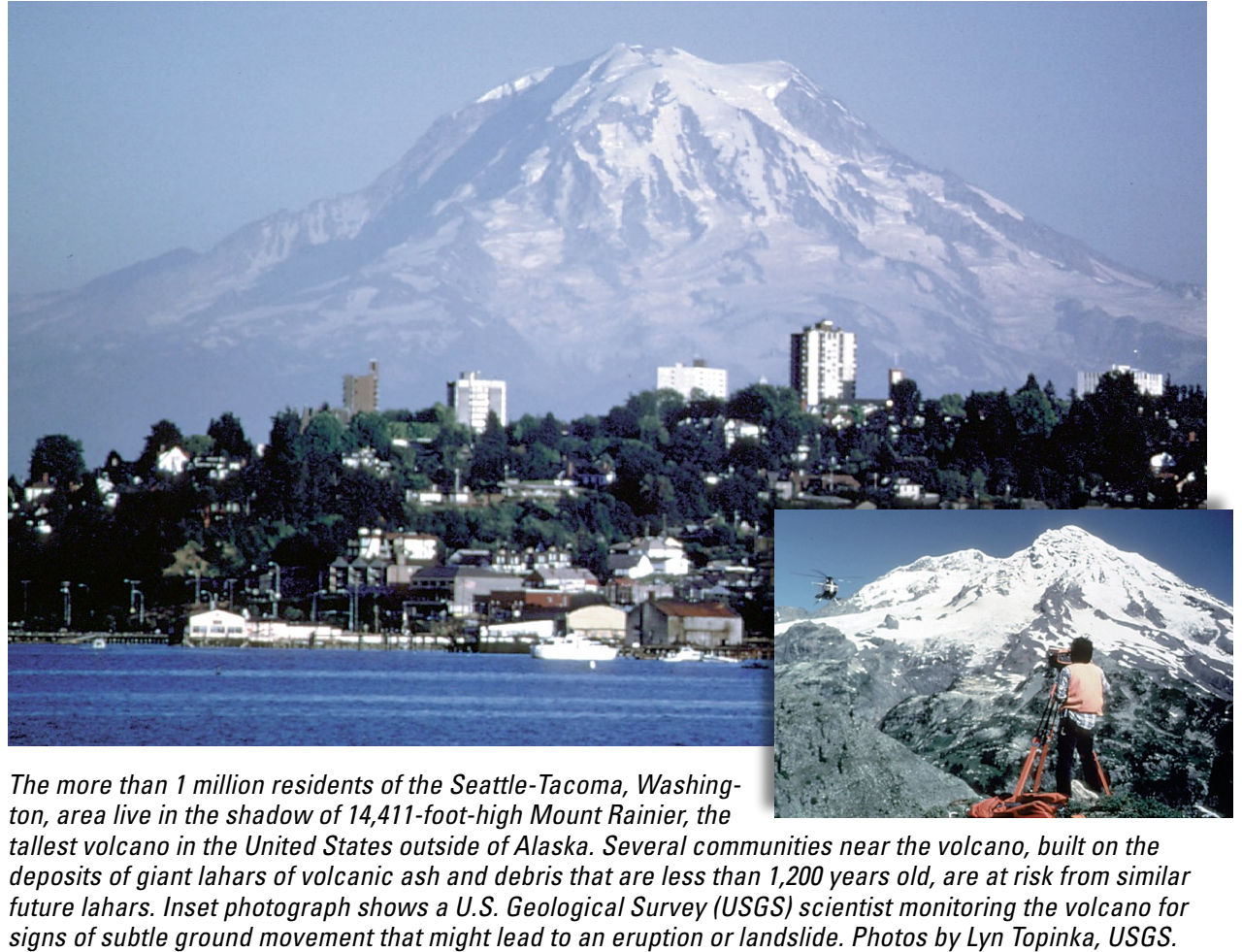

(pyroclastic flows), lava flows, and landslides can devastate areas 10 or more miles away; and huge mudflows of volcanic ash and debris, called lahars, can inundate valleys more than 50 miles downstream. Falling ash from explosive eruptions can disrupt human activities hundreds of miles downwind, and drifting clouds of fine ash can cause severe damage to jet aircraft even thousands of miles away.

Because the population of the Pacific Northwest is rapidly expanding, the volcanoes of the Cascade Range in Washington, Oregon, and northern California are some of the most dangerous in the United States.

\section{Washington}

Mount Baker erupted in the mid-1800s for the first time in several thousand years. Activity at steam vents (fumaroles) in Sherman Crater, near the volcano's summit, increased in 1975 and is still vigorous, but there is no evidence that an eruption is imminent.

Glacier Peak has erupted at least six times in the past 4,000 years. About 13,000 years ago, an especially powerful series of eruptions deposited volcanic ash at least as far away as Wyoming.

Mount Rainier has produced at least ten eruptions and numerous lahars in the past 4,000 years. It is capped by more glacier ice than the rest of the Cascade volcanoes combined, and parts of Rainier's steep slopes have been weakened by hot, acidic volcanic gases and water. These factors make this volcano especially prone to landslides and lahars.

Mount St. Helens is the most frequently active volcano in the Cascades. During the past 4,000 years, it has produced many lahars and a wide variety of eruptive activity, from relatively quiet outflows of lava to explosive eruptions much larger than that of May 18, 1980.

Mount Adams has produced few eruptions during the past several thousand years. This volcano's most recent activity was a series of small eruptions about 1,000 years ago.

\section{Oregon}

Mount Hood last erupted about 200 years ago, producing pyroclastic flows, lahars, and a prominent lava dome (Crater Rock) near the 
volcano's summit. Most recently, a series of steam blasts occurred between 1856 and 1865 .

Mount Jefferson last erupted more than 20,000 years ago. However, eruptions nearby have produced several lava flows and small volcanic cones in the past 10,000 years.

Three Sisters Volcanic Center in central Oregon includes five large volcanoes-North Sister, Middle Sister, South Sister, Broken Top, and Mount Bachelor. About 2,000 years ago, eruptions occurred on South Sister, as well as from several small volcanoes north of North Sister. Since 1997, a broad area centered 3 miles west of South Sister has domed upward by more than 8 inches. Scientists think that this doming reflects the ongoing accumulation of magma at a depth of 3 to 4 miles. The outcome of this activity is uncertain, but there is no evidence that an eruption is imminent. The USGS and its partners have increased monitoring efforts in the area to detect any changes that might warrant more concern.

Newberry Volcano, a broad shield covering more than 500 square miles, is capped by Newberry Crater, a large volcanic depression (caldera) 5 miles across. Its most recent eruption was about 1,300 years ago.

Crater Lake occupies a 6-mile-wide caldera formed 7,700 years ago when the summit of an ancient volcano (referred to as Mount Mazama) collapsed during a huge explosive eruption. More than 10 cubic miles of magma was erupted, 10 times as much as in any other eruption in the Cascades during the past 10,000 years. Smaller eruptions ending about 5,000 years ago formed Wizard Island and several submerged cones and lava domes on the lake floor.

\section{Northern California}

Medicine Lake Volcano, a broad shield capped by a 4- by 7-mile-wide caldera, has erupted at least seven times in the past 4,000 years, most recently about 950 years ago. With a volume of more than 130 cubic miles, it is the largest volcano in the Cascades.

Mount Shasta has been the most active volcano in California during the past 4,000 years. During that time, Shasta has erupted on average about once every 300 years, producing many pyroclastic flows and lahars. It probably last erupted in 1786.

Lassen Volcanic Field, including Lassen Peak, is the southernmost volcanic center in the Cascades. The most recent volcanic eruptions in California occurred at Lassen Peak from 1914 to 1917. An explosive eruption on May 22, 1915, produced a large

Of the 13 potentially active volcanoes in the Cascade Range of the Pacific Northwest, 11 have erupted in the past 4,000 years. More than 100 eruptions, most of which were explosive, have occurred during that period, making the volcanoes of the Cascade Range some of the most hazardous in the United States.

Each eruption

symbol in the diagram represents from one to several eruptions closely spaced in time at or near the named volcano. Eruptions have also occurred from other vents (not shown) scattered throughout the Cascade Range, especially in central Oregon and southwestern Washington.

pyroclastic flow, lahars, and ash that fell as far away as Elko, Nevada, 300 miles to the east.

\section{Reducing the Risk}

After the 1980 eruption of Mount St. Helens, Congress provided increased funding that enabled the USGS to establish a volcano observatory for the Cascade Range. Located in Vancouver, Washington, the David A. Johnston Cascades Volcano Observatory (CVO) was named for a USGS scientist killed at a forward observation post by the May 18, 1980, eruption.

Scientists at CVO quickly recognized that it was not economically feasible to fully monitor all potentially active Cascade volcanoes. To address this and similar problems elsewhere in the United States and abroad, the USGS developed a suite of portable volcanomonitoring instruments — essentially, a portable volcano observatory. In the Pacific Northwest, when regional networks of earthquake sensors, operated in cooperation with the University of Washington's Pacific Northwest Seismic Network, detect unusual seismic activity at a volcano, CVO staff will rapidly deploy this portable equipment to evaluate the hazard and, if needed, provide timely warnings to local officials and the public.

CVO also uses remote sensing as an early-detection tool. A technique called interferometric synthetic-aperture radar (InSAR) allows scientists to measure subtle movements of the ground surface, using radar images obtained by Earth-orbiting satellites. The current ground doming at Three Sisters was first detected using this technique.

CVO was able to issue accurate warnings of the small eruptions that occurred in 1980-86 and in 2004 at Mount St. Helens. Observatory scientists also have conducted many new studies of the past geologic behavior of Cascade volcanoes. These studies allow assessments of long-term hazards (including lahars and landslides, which can occur even when a volcano is not erupting) and provide the data for hazard-zone maps that enable communities to make wise land-use-planning decisions and to prepare emergency-response plans.

The work of CVO scientists is helping residents of the Pacific Northwest live with volcanic risk and plan for volcano emergencies. This work is only part of the USGS Volcano Hazards Program's ongoing efforts to protect people's lives and property in all of the volcanic regions of the United States, including the Pacific Northwest, eastern California, Wyoming, Alaska, and Hawaii.

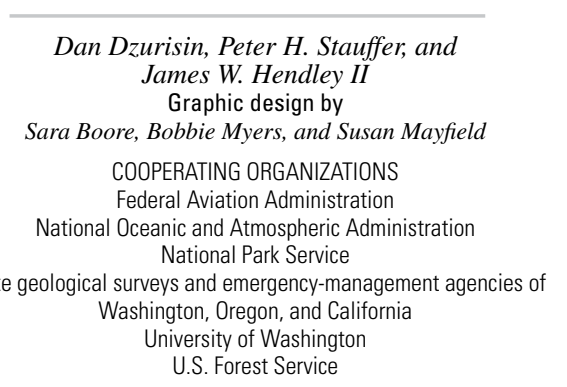

For more information contact: U.S. Geological Survey

David A. Johnston Cascades Volcano Observatory

1300 SE Cardinal Court, Building 10, Suite 100 , Vancouver, WA 98683

Tel: (360) 993-8900, Fax: (360) 993-8980 e-mail: cvo@usgs.gov

URL: http://vulcan.wr.usgs.gov/ or

USGS Volcano Hazards Program http://volcanoes.usgs.gov/

This Fact Sheet and any updates to it are available online at: http://pubs.usgs.gov/fs/1997/fs165-97/

See also What Are Volcano Hazards? (USGS Fact Sheet 002-97) Mobile Response Team Saves Lives in Volcano Crises (USGS Fact Sheet 064-97) 